\title{
INFLUENCE OF FEEDING DIFFERENT TYPES OF OLIGOSACCHARIDES ON GROWTH PERFORMANCE, DIGESTIBILITY AND SOME BLOOD PARAMETERS OF FATTENING EGYPTIAN BUFFALO STEERS
}

\author{
M. Abd-Allah ${ }^{1}$, E.H.S. Hassan ${ }^{1}$ and M.W.H. Daghash ${ }^{2}$ \\ 1-Department of Animal Production, Faculty of Agriculture, Al-Azhar University, Assiut Branch, Assiut71524, Egypt. \\ 2-Department of Animal Production, Faculty of Agriculture, Assiut University, Assiut 71515, Egypt \\ *E-mail:mohtaram_a_m_e@yahoo.com,muhtaram@azhar.edu.eg
}

Received: 4/9/2019 Accepted: 18/3/2020

\section{SUMMARY}

A total of sixteen Egyptian male buffalo steers aged 28 months weighted $330.08 \pm 10.63 \mathrm{~kg}$ were used in this trial to elucidate the impact of using three types of oligosaccharides (Mannan oligosaccharide (Bio-Mos ${ }^{\circledR}$ ), Esterified glucomannan $\left(E G M-100^{\circledR}\right)$ and Galacto oligosaccharides $\left(G O S^{\circledR}\right)$ on growth, feed conversion, digestibility coefficients, economic efficiency and some blood parameters. At the beginning of the experiment, animals were randomly allotted into four equal groups (4animals each) according to average body weight. Treated animals in the control group $(\mathrm{CO})$ were fed on the control diet without oligosaccharides, while those in MOS, EGM and GOS groups were fed on diets containing $0.1 \%$ of each type of oligosaccharides ( $1 \mathrm{~g} / \mathrm{kg}$ diet) for 120 days feeding period. Four digestibility trials were carried out to determine nutrients digestibility and nutritive values of experimental diets. Results revealed that digestibility coefficients of DM, OM, CF and NFE tended to increase significantly by feeding buffalo steers on MOS and EGM diets compared with those of control group. Likewise, there were significant differences $(P \leq 0.05)$ in $C P$ and EE digestibility among groups treated with MOS and EGM than control group. The present results showed a significant $(P \leq 0.01)$ increase of nutritive values as TDN and ME for MOS and EGM diets compared with control. Feeding male buffalo on treated diets increased $(P \leq 0.05)$ the nutritive value as DCP compared with untreated ones. Live body weight was significantly $(P \leq 0.05)$ increased as well as $A D G$ and $T G$ were improved $(P \leq 0.01)$ in treated trials. There was no significant increase in daily dry matter (DMI), total digestible nutrient intake (TDNI), digestible crude protein intake (DCPI) and metabolizable energy $(M E)$ due to oligosaccharide supplementation. Feeding male buffaloes on MOS and EGM decreased ( $P \leq 0.01)$ feed conversion of DM and TDN compared with control group. Total feed coast (LE/kg gain) was decreased due to feeding MOS and EGM supplemented diets. Feeding MOS and EGM increased $(P \leq 0.05)$ total protein and globulin levels of blood serum which might indicate improvement of immune status of treated animals. Means of alanine transaminase (AST) and aspartate transaminase (ALT) enzymes did not differ significantly among treatments. Blood serum total lipids were reduced $(P \geq 0.05)$, while total cholesterol concentration was $(P \leq 0.05)$ lower in blood serum of treated groups than control and the lowest values were recorded for GOS group. It was concluded that prebiotics supplementation (such as oligosaccharides) in the diet offatting male Egyptian buffaloes resulted in significant improvement in productive performance and digestibility coefficients without any harmful effect on animals health.

Keywords: Egyptian buffalo, fattening performance, oligosaccharides, blood metabolites, nutrient digestibility

\section{INTRODUCTION}

The modern animal production system in the world is searching eco-friendly and healthy means for the enhancement of animal productivity in general and meat animal production in particular. In the recent years, Poeikhampha and Bunchasak (2011) used feed additive as an alternative to the antibiotics as growth promoter and control diseases in livestock's feed especially, in the modern or intensive farming system. Many countries are either regulating the use of antibiotics in feed or setting up programs to reduce the overall use of antibiotic. In ruminants alternatives to these materials have been studied for several years, such as probiotics or prebiotics. Gibson and Roberfroid (1995) defined prebiotics as nondigestible carbohydrates that can be able to beneficially modify the growth and/or activity of the intestinal bacterial populations towards a healthier microflora and improve indices of host health.

Ghosh and Mehla (2012) found that oligosaccharides are promising alternatives to antibiotic growth promoters because they facilitate and support the symbiotic relationship between host and microflora. Duan et al., (2016) added that, functional oligosaccharides are widely used in animal feed because of the benefits to animal growth and immunity. Fructo oligosaccharides (Grand et al., 2013), galacto oligosaccharides (Kanakupt et al., 2011) and mannan oligosaccharides (Ghosh and 
Mehla, 2012) have been utilized as prebiotics for animals. Most previous studies concentrated on monogastric animals, because it is believed that oligosaccharides are degraded by ruminal microbes and therefore bring no additional benefit to ruminant diets. However, a small number of studies showed a benefit of oligosaccharides to ruminants (Zheng et al., 2018).

Mannan oligosaccharides(MOS) was found to limit body condition scoring (BCS) loss following parturition in spring-calving beef cows (Linneen et al., 2014), and increased concentrate intake in very young pre-wean dairy calves without affecting their performance (Morrison et al., 2010). Similarly, Franklin et al., (2005) found that during the dry period, supplemented cows to MOS enhanced their immune response to rotavirus and the subsequent transfer of rotavirus antibodies to their calves. In some studies, Daghash, (2015) found that average daily gain, feed intake were increased and feed conversion were improved in rams fed MOS in their diets. In addition, Heinrichs et al. (2013) illustrated that average daily weight gain (ADG) and feed efficiency were increased in calves fed diets supplemented with MOS.

Therefore, the objective of the current study was to investigate the effects of adding different types of oligosaccharides to buffalo diets on the nutrients digestibility, productive performance and some blood parameters.

\section{MATERIALS AND METHODS}

The experiment was conducted at the Animal Experimental Farm, Animal Production Department, Faculty of Agriculture, Al-Azhar University Assiut branch, Assiut, Egypt.

\section{Animals and management:}

A total of 16 Egyptian male buffaloes aged 28 months were used in this trial to elucidate the impact of using three types of oligosaccharides Mannan oligosaccharide (Bio-Mos ${ }^{\circledR}$ ), Esterified glucomannan $\left(\right.$ EGM-100 ${ }^{\circledR}$ ) and Galacto oligosaccharides $\left(\right.$ GOS $\left.^{\circledR}\right)$ on weight gain, feed efficiency, digestibility coefficients, economic efficiency and some blood parameters. At the beginning of the experiment, tested animals were randomly allotted into four equal groups (four animals each). Average initial body weight was almost the same $(330.08 \pm 10.63 \mathrm{~kg})$ in all treatment groups. Treated animals in the control group (CO) were fed the control diet without oligosaccharides, while those in MOS, EGM and GOS groups were fed the control diet with $0.1 \%$ oligosaccharides $(1 \mathrm{~g} / \mathrm{kg}$ diet $)$. The tested oligosaccharides are commercially available as BioMos ${ }^{\circledR}$, EGM-100 ${ }^{\circledR}$ GOS $^{\circledR}$ which are a nutritional supplements manufactured by MOS, EGM and GOS Matrix nutrition, LLC, USA. The concentrate diet was consisted of $46 \%$ yellow corn, $22 \%$ wheat bran, $15 \%$ decorticated cotton seeds meal, $14 \%$ soybean meal,1\% Vitamin-mineral $\left(\right.$ Premix $\left.^{\circledR}\right)$ ), $1 \%$ limestone and $1 \%$ sodium chloride. Animals were individually fed twice at 7:00 a.m. and 3 p.m. daily. The green fodder (Egyptian clover, Trifolium alexandrinum) was fed to animals in the afternoon (4:00 p.m), wheat straw was offered ad libitum. While, fresh water was offered three times daily at 8:00, 12:00 a.m and 5:00 p.m.

\section{Productive performance}

Animals were weighed at the beginning of the experiment in the morning before feeding and monthly thereafter to detect body weight changes. Feed consumption was determined, live weight gain and feed conversion ( $\mathrm{kg}$ feed / $\mathrm{kg}$ gain) were calculated. The ingredients of the diet used and approximate analysis are shown in Table (1). Chemical analysis Table (1) was carried out for diet samples according to A.O.A.C methods (2005).The animals were fed on tested diets all the time $a d$ lib during the experimental period (120days).

Table 1. Ingredients and chemical analysis $(\%)$ of the experimental diets

\begin{tabular}{|c|c|c|c|c|}
\hline Item & Ingredient, \% & \multicolumn{3}{|c|}{ Chemical analysis (\% DM basis) } \\
\hline & & & CFM & Wheat straw \\
\hline Corn & 46 & DM & 90.85 & 91.78 \\
\hline Wheat Bran & 22 & $\mathrm{OM}$ & 93.32 & 89.24 \\
\hline Undecorticated cottonseed meal & 15 & $\mathrm{CP}$ & 16.68 & 3.15 \\
\hline Soybean meal & 14 & $\mathrm{CF}$ & 6.01 & 40.22 \\
\hline Vitamin-mineral $\left(\right.$ Premix $\left.^{\circledR}\right)$ & 1 & $\mathrm{EE}$ & 3.20 & 1.96 \\
\hline Calcium carbonate (Limestone) & 1 & NFE & 67.43 & 45.33 \\
\hline Sodium chloride (Salt) & 1 & Ash & 6.68 & 10.76 \\
\hline
\end{tabular}

\section{Apparent digestibility coefficients:}

Biological assay was designed to evaluate differences in digestibility values of different nutrients (CP, EE, CF, NFE, Ash, DM and OM) for the four experimental diets used throughout the experiment. Four digestibility trials were carried out to determine nutrient digestibility and nutritive values of the experimental diets. At the end of the feeding period twelve animals (three from each) were chosen randomly for each digestibility trial. Animals were healthy and in good condition at all periods. Animals were individually housed in metabolic cages supported by metal feces for feces collection. The experiment diets were offered daily ad lib for 22 days (primary period 15 days and collection period 7 days). Fresh water was provided all the time. All 
animals were weighed at the beginning and at the end of the collection period to make sure that their weights were maintained. Feces produced daily were collected in polyethylene bags and stored at $-20^{\circ} \mathrm{C}$ for seven consecutive days. The dried feces (drying in an electric oven at $65 \mathrm{C}$ for $48 \mathrm{~h}$ ) from each replicate during the seven collection days were mixed together, weighed, finely ground and stored in plastic bags. Samples of feeds and excreta were used for chemical analysis to determine digestibility values. Samples of diets and feces were analyzed for their content of protein, fat, fiber, and NFE (carbohydrate by difference) according to (A.O.A.C., 2005). The NFE was calculated according to the following equation: $\mathrm{NEF} \%=100-(\% \mathrm{CP}+\% \mathrm{EE}+\% \mathrm{CF}+$ $\%$ Ash). Nutrients digestibility values of experimental trials were estimated on DM basis. Values of TDN and DCP were calculated according to Weiss (1999).

\section{Blood sampling and analytical methods:}

Blood samples (about $7 \mathrm{ml}$ of each sample) were obtained before feeding, from all experimental animals at the end of experimental trial (120 days) and resumed by Jugular vein puncture and transferred to dry clean 10-ml centrifuge tube. Blood samples were allowed to clot at room temperature and serum was then separated by centrifugation at 3000 r.p.m. for 15 minutes. Serum was decanted into clean dry glass vials and stored at $-20^{\circ} \mathrm{C}$ until subsequent analyses. Blood serum was used to estimate total protein $(\mathrm{g} / \mathrm{dl})$, albumin $(\mathrm{g} / \mathrm{dl})$, total lipids $(\mathrm{mg} / \mathrm{dl})$, total cholesterol $(\mathrm{mg} / \mathrm{dl})$ and alanine transaminase (ALT) and aspartate transaminase enzymes (AST) using kits supplied by Diamond Diagnostics (Egypt). Serum total globulins concentration was determined by difference between serum total protein and serum albumin and albumin/globulin ratio was calculated.

\section{Economic efficiency:}

Economic efficiency for all the experimental diets was estimated. Economic efficiency is defined as the net revenue per unit feed cost calculated from input output analysis as described by Hassan et al. (1996).

\section{Statistical analysis:}

The data were analyzed according to SAS System (2004). Significant differences among treatments were determined using Duncan's News Multiple Range Test (DMRT) (Steel and Torrie, 1980). Data on apparent nutrients digestibility and nutritive value of diets, feed intake, body weight, body weight gain and blood parameters were analyzed by one -way analysis of variance according to the mathematical model : $\mathrm{Y}_{\mathrm{ij}}=\mu+\tau_{\mathrm{i}}+\varepsilon_{\mathrm{ij}}$. Where $\mathrm{Y}=$ observations, $\mu=$ overall mean, $\tau=$ the effect of $i^{\text {th }}$ treatments $(i=1,2,3$, 4 ), where $\tau_{1}$ control, $\tau_{2}$ effect of MOS, $\tau_{3}$ effect of EGM and $\tau_{4}$ effect of GOS, and $\varepsilon_{\mathrm{ij}}=$ The random error.

\section{RESULTS AND DISCUSSION}

\section{Digestibility coefficients and nutritive values of dietary treatments:}

In general, digestibility coefficients of DM, OM, $\mathrm{CF}$ and NFE tended to increase significantly by feeding male buffaloes on MOS and EGM diets compared with those of the control group (Table 2). Likewise, there were significant differences $(P \leq 0.05)$ in the $\mathrm{CP}$ and $\mathrm{EE}$ digestibility between animals treated with oligosaccharides and the control group (Table 2). The present results showed a significant $(P \leq 0.01)$ increase in nutritive values as TDN and ME for MOS and EGM diets compared with the control one. Feeding male buffaloes on treated diets increased $(P \leq 0.05)$ the nutritive value as DCP compared with untreated one. The results in Table 2 indicated that, buffalo steers treated with GOS showed the lowest $(P \leq 0.01$ or $P \leq 0.05)$ digestibility coefficients of DM, OM, CF and NFE compared to MOS, EGM and control groups, consequently, there is a significant $(P \leq 0.01)$ decrease in the nutritional values of TDN, DCP and ME, Mcal of GOS group compared to the other groups. This decrease may be due to effects of three oligosaccharides on metabolism of intestinal microflora (Djouzi and Andlueux, 1997), or because the different chemical composition of oligosaccharides and carbohydrate fermentation produces absorption as reported Macfarlane and Cummings, (1991) where he mentioned that, fermentation of carbohydrates produces metabolites, short chain fatty acids (SCFA), lactic acids and gases in proportions depending on the chemical composition of carbohydrates and bacteria involved. Zheng et al., (2018) stated that MOS promotes cellulolytic bacteria, causing a greater degradation of fiber in the rumen; and promotes ruminal microbes to synthesize more degradable microbial protein to increase $\mathrm{N}$ digestion. Attia et al., (2015) found that addition of MOS to the basal diet of rabbits increased $(P \leq 0.01)$ digestibility of dry matter, organic matter, ash and crude fiber compared with control group. They added that feeding young rabbits on MOS in the diet improved $(P \leq 0.01)$ digestibility coefficient of $\mathrm{CP}$ and NFE when compared with other groups. Furthermore, Daghash, (2015) suggested that the increase in long villi would increase the surface area that is capable of great absorption of available nutrients by MOS. While great villus height and more numerous cell mitosis in the intestine are indicators that the function of intestinal villi is activated (Yasar and Forbes, 1999). The present results are in agreement with those obtained by Zheng et al., (2018) who found in sheep a tendency of MOS to increase the NDF and ADF apparent digestibility and $\mathrm{N}$ retention. In the contrast, Diaz et al. (2018) found that daily intake of $\mathrm{DM}, \mathrm{CP}, \mathrm{NDF}$ and $\mathrm{EE}$ were not affected $(P \geq 0.05)$ by the addition of Yeast or MOS in Holstein steers fed grain-based diets. Jin et al. (2014) observed that MOS did not affect apparent nutrient digestibility in steers. 
Table 2. Effect of treatments on digestibility coefficients $(\%)$ and nutritive values $(\%)$ of experimental diets $(\mathbf{L S M} \pm \mathbf{S E})$

\begin{tabular}{|c|c|c|c|c|c|c|}
\hline \multirow{2}{*}{ Item } & \multicolumn{4}{|c|}{ Experimantal diets } & \multirow{2}{*}{ SEM } & \multirow{2}{*}{ Sig. } \\
\hline & $\mathrm{CO}$ & MOS & EGM & GOS & & \\
\hline \multicolumn{7}{|c|}{ Digestibility coefficients, \% } \\
\hline $\mathrm{DM}$ & $62.23^{\mathrm{b}}$ & $62.35^{\mathrm{ab}}$ & $63.07^{\mathrm{a}}$ & $60.96^{\mathrm{c}}$ & 0.254 & $* *$ \\
\hline $\mathrm{OM}$ & $66.16^{\mathrm{b}}$ & $66.18^{\mathrm{b}}$ & $66.94^{\mathrm{a}}$ & $64.92^{\mathrm{c}}$ & 0.242 & $* *$ \\
\hline $\mathrm{CP}$ & $77.02^{\mathrm{a}}$ & $77.03^{\mathrm{a}}$ & $77.53^{\mathrm{a}}$ & $76.20^{\mathrm{b}}$ & 0.265 & $*$ \\
\hline $\mathrm{EE}$ & $52.39^{\mathrm{a}}$ & $52.06^{\mathrm{a}}$ & $52.29^{\mathrm{a}}$ & $49.59^{b}$ & 0.662 & * \\
\hline $\mathrm{CF}$ & $57.63^{\mathrm{b}}$ & $63.51^{\mathrm{a}}$ & $63.74^{\mathrm{a}}$ & $61.67^{\mathrm{a}}$ & 1.301 & $* *$ \\
\hline NFE & $71.39^{\mathrm{b}}$ & $71.48^{\mathrm{b}}$ & $72.46^{\mathrm{a}}$ & $70.57^{\mathrm{c}}$ & 0.253 & $* *$ \\
\hline \multicolumn{7}{|l|}{ Nutritive values, \% } \\
\hline TDN & $68.23^{\mathrm{bc}}$ & $68.62^{\mathrm{b}}$ & $69.39^{\mathrm{a}}$ & $67.58^{\mathrm{c}}$ & 0.236 & $* *$ \\
\hline $\mathrm{DCP}$ & $12.85^{\mathrm{a}}$ & $12.85^{\mathrm{a}}$ & $12.93^{\mathrm{a}}$ & $12.71^{\mathrm{b}}$ & 0.043 & $* *$ \\
\hline ME, Mcal/kg DM* & $2.458^{\mathrm{bc}}$ & $2.471^{\mathrm{b}}$ & $2.498^{\mathrm{a}}$ & $2.432^{\mathrm{c}}$ & 0.02 & $* *$ \\
\hline
\end{tabular}

\section{Live body weight and daily gain:}

Feeding buffaloes on MOS, EGM and GOS increased significantly $(P \leq 0.05)$ live body weight when compared with control (CO) group as shown in Table (3). Means of body weights at the end of the experimental period (120 days) were 433.3, 426.7, 421 vs. $410 \mathrm{~kg}$, respectively. Daily and total weight gain were improved $(P \leq 0.01)$ as a function of feeding tested oligosaccharides (MOS, EGM and GOS) in treated male buffaloes when compared with control group. MOS, EGM and GOS supplementation groups increased $(P \leq 0.05)$ daily gain by about $24.50 \%$,
$18.40 \%$ and $11.03 \%$, respectively in comparison with control. Data revealed that diet contained MOS appeared the best group than other treated groups. Similar results were observed in previous studies by Mandour et al., (2010) on Najdi sheep, Fath-Allah (2006) for crossbred lambs, Jayabal et al. (2008) for goat kids. In addition, Ghosh and Mehla (2012) found in Holstein cross calves that there was a significant increase $(P \leq 0.01)$ in average body weight gain by about $22 \%$ in MOS treated group compared with control.

Table 3. Effect of oligosaccharides on live body weight and feed intake of male buffalo steers (LSM \pm SE)

\begin{tabular}{|c|c|c|c|c|c|c|}
\hline \multirow{2}{*}{ Item } & \multicolumn{4}{|c|}{ Experimantal diets } & \multirow{2}{*}{ SEM } & \multirow{2}{*}{ Sig. } \\
\hline & $\mathrm{CO}$ & MOS & EGM & GOS & & \\
\hline \multicolumn{7}{|l|}{ Live body weight $(\mathrm{kg})$} \\
\hline Intial body weight & 328.33 & 331.67 & 330.00 & 330.330 & 10.63 & $\mathrm{~ns}$ \\
\hline Final body weight & $410.00^{b}$ & $433.33^{\mathrm{a}}$ & $426.67^{\mathrm{ab}}$ & $421.00^{\mathrm{ab}}$ & 10.12 & $*$ \\
\hline Total gain (kg) & $81.70^{c}$ & $101.56^{\mathrm{a}}$ & $96.69^{\mathrm{ab}}$ & $90.77^{\mathrm{b}}$ & 19.86 & $* *$ \\
\hline Average daily gain $(\mathrm{g})$ & $680.8^{\mathrm{c}}$ & $846.3^{\mathrm{a}}$ & $805.8^{\mathrm{ab}}$ & $756.4^{\mathrm{b}}$ & 19.86 & $* *$ \\
\hline \multicolumn{7}{|l|}{ Feed intake, kg. } \\
\hline $\mathrm{DMI} / \mathrm{h} / \mathrm{d}$ & 7.46 & 7.53 & 7.49 & 7.50 & 0.24 & ns \\
\hline $\mathrm{TDNI} / \mathrm{h} / \mathrm{d}$ & 5.09 & 5.17 & 5.20 & 5.07 & 0.15 & $\mathrm{~ns}$ \\
\hline $\mathrm{DCPI} / \mathrm{h} / \mathrm{d}$ & 0.959 & 0.968 & 0.968 & 0.953 & 0.11 & $\mathrm{~ns}$ \\
\hline $\mathrm{ME}, \mathrm{Mcal} / \mathrm{h} / \mathrm{d}$ & 1.834 & 1.814 & 1.871 & 1.824 & 0.02 & ns \\
\hline
\end{tabular}

$\overline{\text { a,b,c }}$ means in the same raw with different superscripts differ significantly at $(\mathrm{P}<0.05)$. DMI= Dry mater intake, TDNI= total digestible nutrient intake, DCPI= digestible crude protein intake, ME= metabolizable energy, SEM = Standard error mean. *Significant at 5\% level, ** Significant at $1 \%$ level. ns= no significant. $\mathrm{CO}=\mathrm{Control}$; MOS=Mannan oligosaccharides; EGM $=$ Esterified glucomannan; GOS $=$ Galacto oligosaccharides . 
Daily dry mater (DMI), total digestible nutrient intake (TDNI) and metabolizable energy (ME) did not differ among group, Similarly daily digestible crude protein intake (DCPI) was insignificantly increased as a function of feeding treated oligosaccharides compared with untreated one (Table 2). Increase body weight and improve daily gain of oligosaccharides treated animals may be attributed to the directly modulating the gut microbiota. The mechanism to promote growth performance with MOS is probably focused on intestinal morphology and nutrients utilization of ruminants, there are several investigator agree with this assumption (Demirel et al., 2007 and Zhao et al., 2012). Davis et al. (2002) found that MOS supplementation in pig diets improved nutrients utilization (digestion and absorption). Liu et al. (2008) indicated in weaning pigs that diets supplemented with chitooligosaccharide (COS) at 100 and $200 \mathrm{mg} / \mathrm{kg} \mathrm{LBW}$ enhanced growth performance by increasing apparent digestibility, decreasing the incidence of diarrhea and improving small intestinal morphology. There is substantial evidence that dietary MOS modifies the morphology and structure of the intestinal mucosa and may change digestive enzyme activities and amino acid transport in the digestive system (Iji et al., 2001).

\section{Feed conversion and economic efficiency:}

Feeding male Egyptian buffaloes on MOS, EGM and GOS decreased $(P \leq 0.01)$ feed conversion of DM, TDN and DCP compared with the control group (Table 4). These results may be attributed to the high digestibility which recorded particularly for groups supplemented by oligosaccharides (MOS, EGM and GOS) which led to increase the absorbed of nutrients from small intestine, consequently increase body weight gain and efficiency of feed utilization and to high daily gain of the experimental groups than the control one. These results are in agreement with those obtained by Daghash, (2015) who showed that feed conversion of MOS treated rams was lower than that of control group. Similar results were obtained in young calves (Ghosh and Mehla, 2012), pigs (Davis et al., 2002).

Table 4. Effect of treatments on feed conversion and econmic efficiency of male buffalo steers (LSM \pm SE)

\begin{tabular}{|c|c|c|c|c|c|c|}
\hline \multirow{2}{*}{ Item } & \multicolumn{4}{|c|}{ Experimantal diets } & \multirow{2}{*}{ SEM } & \multirow{2}{*}{ Sig. } \\
\hline & $\mathrm{CO}$ & MOS & EGM & GOS & & \\
\hline \multicolumn{7}{|c|}{ Feed conversion (intake/kg gain) } \\
\hline $\mathrm{DM}$ & $9.13^{\mathrm{a}}$ & $7.44^{\mathrm{b}}$ & $7.76^{b}$ & $8.28^{\mathrm{ab}}$ & 0.340 & $* *$ \\
\hline TDN & $5.91^{\mathrm{a}}$ & $4.82^{\mathrm{b}}$ & $5.07^{\mathrm{b}}$ & $5.26^{\mathrm{ab}}$ & 0.214 & $* *$ \\
\hline DCP & $1.40^{\mathrm{c}}$ & $1.80^{\mathrm{c}}$ & $2.57^{\mathrm{b}}$ & $3.492^{\mathrm{a}}$ & 0.135 & $* *$ \\
\hline \multicolumn{7}{|l|}{ Economic efficiency } \\
\hline Feed cost, $\mathrm{LE} / \mathrm{h} / \mathrm{d}$ & 41.01 & 41.43 & 41.22 & 41.26 & 1.33 & $\mathrm{~ns}$ \\
\hline Feed cost, LE/kg gain & $50.20^{\mathrm{a}}$ & $40.92^{\mathrm{b}}$ & $42.65^{\mathrm{b}}$ & $45.57^{\mathrm{ab}}$ & 1.87 & $* *$ \\
\hline Economic efficiency ${ }^{1}$ & $1.10^{\mathrm{b}}$ & $1.35^{\mathrm{a}}$ & $1.29^{\mathrm{a}}$ & $1.21^{\mathrm{ab}}$ & 0.06 & $* *$ \\
\hline RFE \% & 100 & 122.7 & 117.3 & 110.0 & & \\
\hline
\end{tabular}

${ }^{a, b, c}$ means in the same raw with different superscripts differ significantly at $(\mathrm{P} \leq 0.05)$.SEM $=$ Standard error mean. $* *$ Significant at $1 \%$ level. $\mathrm{ns}=$ no significant. $\mathrm{CO}=$ Control. $\mathrm{MOS}=$ Mannan oligosaccharides; $\mathrm{EGM}=$ Esterified glucomannan and GOS $=\mathrm{Galacto}$ oligosaccharides. A price of 1 ton $\mathrm{CFM}=5500$ and wheat straw $=400 \mathrm{LE}$. Price of $1 \mathrm{~kg}$ live body weight $=55 \mathrm{LE}$ as the dominant market price of finishing buffalo calves at Assiut market in this period, respectively. 1-Economic efficiency = price of one kg LBW (LE/kg gain) / feed cost (LE/kg gain). RFE = Assuming that the relative economic efficiency (RFE) of the control diet equal 100.

Total feed cost $(\mathrm{LE} / \mathrm{h} / \mathrm{d})$ did no influence due to feeding oligosaccharides treatments compared with the control, while total feed coast ( $\mathrm{LE} / \mathrm{kg}$ gain) was decreased due to feeding MOS and EGM supplemented diets (Table 4). Economic efficiency increased $(P \leq 0.01)$ when feeding male buffalo on MOS and EG M compared with the control diet. Similarly, relative economic efficiency was increased by about 122.7, 117.3 and 110.0, respectively compared with (100\%) in CO due to feeding fatting buffalo on MOS, EGM and GOS when compared with the CO diet. Decreasing total feed cost is due to the decrease in feed intake and cost of $\mathrm{kg}$ feed.

\section{Blood metabolites}

The effect of dietary fortification with MOS, EGM or GOS on some selected serum parameters of Egyptian male buffalo at end of 4 months experimental trial is shown in Table (5). The supplementation of MOS and EGM significantly $(P \leq 0.05)$ increased both blood serum total protein
(TP) and total globulin (GL) as compared to control group (Table 5). Mean concentrations of serum albumin (AL) and AL/GL ration did not differ significantly due to treatments. There was a tendency for lower ALGL ratio in male buffaloes fed treated diets than those fed untreated one. It should be noted that the AL/GL ratio gives a decrease in albumin production by the liver which reflects normal hepatic function. Franklin et al. (2005) reported greater increases in serum total protein concentration from birth to $24 \mathrm{~h}$ in calves from cows fed (MOS) compared with calves from cows fed the control diet. Maha et al., (2012) found in Barki lambs that value of total globulin concentration was increased $(P \leq 0.05)$ in the diet supplemented with EGM compared to control group. Daghash (2015) illustrated that serum total protein and total globulins levels were increased while A/G ratio was decreased in MOS treated rams than in control one. These findings suggest that MOS and EGM may improve 
the immune status of treated animals. Liang et al. (1998) reported that the immune modulatory effect of EGM may be attributed to the ability of beta-(1-3)glucan to non-specifically activate cellular and humoral components of the host immune system and to enhance the functional activity of macrophages. Furthermore, Lowry et al., (2005) added that beta-(13)-glucan also stimulate the proliferation of monocytes and macrophages and have potent hematopoietic activities. In addition, serum total protein level is a general indication of immune status (White et al., 2002).

High serum total protein and globulins concentrations in treated animals may be due to that oligosaccharides treatments stimulates thyroid hormones $\left(\mathrm{T}_{3}\right.$ and $\mathrm{T}_{4}$ ) secretion. Daghash, (2015) found that $\mathrm{T}_{3}$ hormone was increased significantly $(P \leq 0.05)$ while $\mathrm{T}_{4}$ hormone was increased insignificantly in MOS treated rams compared with untreated animals. Thyroid hormones increased metabolic rate (Hadley, 1984), and elevated metabolic rate which lead to increase the production of gamma- globulin (Cornelius and Kaneko, 1963) and total protein (More et al., 1980) in different species of domestic animal. Also, thyroid hormone accelerates cellular reactions in most organs and tissues of the body, including the liver in which these proteins are formed (Smith et al., 1983). In addition, high concentrates intake and/or protein intake of MOS treated rams increased amino acids available for absorption and metabolism (Baillet et al., 1998).

Activity of aspartate transaminase (AST) and alanine transaminase (ALT) in blood serum of male buffalo as affected by experimental diets are presented in Table (5). Means of AST or ALT did not differ significantly among treatments and were within the normal range. These results indicated that treated diets to male buffaloes had no adverse effect on liver function and could have a positive effect on animal health. Maha et al. (2012) found that feed additives as MOS and EGM in fattening Barki lambs diet increased $(P \leq 0.05)$ blood level of AST enzyme, while not affect ALT enzyme compared with control. In this respect, Abdel-Khalek (1995) found that the activity of AST and ALT was affected by quality and quantity of dietary protein.

Table 5. Effect of treatments on blood serum constituents of male buffalo calves

\begin{tabular}{lcccccc}
\hline \multirow{2}{*}{ Item } & \multicolumn{4}{c}{ Experimantal diets } & \multirow{2}{*}{ SEM } & \multirow{2}{*}{ Sig. } \\
\cline { 2 - 5 } & CO & MOS & EGM & GOS & & $*$ \\
Total protein (g/dl) & $7.16^{\mathrm{b}}$ & $7.74^{\mathrm{a}}$ & $7.89^{\mathrm{a}}$ & $7.62^{\mathrm{ab}}$ & 0.18 & $*$ \\
Albumin (g/dl) & 3.89 & 3.31 & 3.73 & 3.42 & 0.22 & $\mathrm{~ns}$ \\
Total globulin (g/dl) & $3.27^{\mathrm{b}}$ & $4.45^{\mathrm{a}}$ & $4.16^{\mathrm{a}}$ & $4.20^{\mathrm{ab}}$ & 0.22 & $*$ \\
A/G ratio & 1.23 & 0.84 & 0.96 & 0.90 & 0.14 & $\mathrm{~ns}$ \\
ALT (IU/dl) & 22.89 & 23.78 & 24.89 & 24.11 & 0.81 & $\mathrm{~ns}$ \\
AST (IU/dl ) & 14.00 & 14.67 & 15.33 & 14.33 & 0.50 & $\mathrm{~ns}$ \\
Total lipids ( mg/dl) & 567.2 & 553.4 & 534.1 & 527.1 & 24.28 & $\mathrm{~ns}$ \\
Total cholesterol (mg/dl ) & $220.9^{\mathrm{a}}$ & $214.2^{\mathrm{a}}$ & $209.4^{\mathrm{ab}}$ & $183.9^{\mathrm{b}}$ & 8.90 & $*$ \\
\hline
\end{tabular}

AST: aspartate amino transaminase (GOT); ALT: alanine amino transaminase (GPT); A/G ratio: albumin to globulin ratio. $*=(P \leq 0.05), \mathrm{ns}=(P \geq 0.05)$.

Data presented in Table (5) showed that levels of total lipids in male buffaloes fed diets containing MOS, EGM and GOS were insignificantly decreased $(P \geq 0.05)$ compared to control group. These results are in agree with those obtained by Abubakr et al., (2014) who showed that supplementation of MOSdiet significantly decreased the elevated serum total lipids concentration in rats fed on fat-enriched diet. Similar results were previously obtained by Roberfroid (2002). In addition, Van Dokkum et al., (1999) indicated that the consumption of prebiotics have no significant effects on blood lipids. Although the available data about the mechanistic effects of prebiotics on lipid metabolism are limited, but Delzenne and Kok (1998) suggested that prebiotics might decrease lipogenic enzyme activities in the liver and thus decrease lipid concentration in blood.

Blood serum cholesterol level was significantly $(P \leq 0.05)$ lower in male buffalo of GOS group compared to other groups (Table 5). Means of MOS and EGM groups did not differ significantly from that of the CO group. Daghash (2015) observed that serum total cholesterol concentration was decreased significantly $(P \leq 0.05)$ due to fed MOS in the diet of Saidi rams compared to the control diet. Antunovic et al., (2010) revealed that addition of $0.4 \%$ MOS in the diet of suckling lambs aged 50 days significantly decreased concentration of total cholesterol in blood compared to the control group. Low level of total serum cholesterol in blood serum of GOS may be attributed to the activity of thyroid hormones. Kaneko (1989) found that serum cholesterol level generally varies inversely with thyroid hormones. Thyroid hormones increased the rate of cholesterol catabolism by liver. Also, Parshad and Singh (1979) found that hypocholesteremia which associated with hypothyroidism is due to augmented cholesterol excretion, and even the increased cholesterol synthesis is insufficient to maintain its normal level.

\section{CONCLUSION}

It is concluded that adding oligos accharides (such as MOS, EGM and GOS) at the rate of $1 \mathrm{~kg} /$ ton of concentrate portion of diets of Egyptian male buffaloes, resulted in a significant improvement in productive performance and digestibility coefficients 
without any harmful effect on biochemical blood constituents. Also, adding oligosaccharides at a rate of $1 \mathrm{~kg} /$ ton of feed can improve the economic return from the fattening process for buffalo.

\section{REFERENCES}

A.O.A.C., 2005. Association of Official Analytical Chemists. Official Methods of Analysis. $17^{\text {th }}$ Ed. Published by the A.O.A.C. Washington, DC, USA.

Abdel-Khalek, E.A., 1995. Possibilities of adaptation to ruminants with feeding on non-congressional sources of proteins. Ph.D. Thesis, Bulgarian Academy, Sofia.

El-Mahmoudy, A. M., F.A. Abdel-Fattah, A.D. Abd El-Mageid and I.M. Gheith., 2014. Effect of the growth promotantmannan-oligosaccharide on the lipogram and organ function profile in hyperlipidemic albino rats. American Journal of Phytomedicine and Clinical Therapeutics, 2: 334347.

Antunovic, Z., I. Maric, I. Matanic, Z. Steiner, J. Novoselec and J. Wagner, 2010. Application of mannan oligosaccharides in nutrition of suckling lambs in extensive breeds. Portal of scientific journal of Croatia, Krmiva, 52(2): 71-76.

Attia, Y.A, R.S. Hamed, A.E. Abd El-Hamid, H.A. Shahba and F. Bovera, 2015. Effect of inulin and mannan-oligosaccharides compared with zincbacitracin on growing performance, nutrient digestibility and hematological profiles of growing rabbits. Animal Production Science, 55(1):80-86.

Baillet, C., G.Cuzon, M.Cousin and C.Keriruer., 1998. Effect of dietary protein levels on growth of penaeusstylirostris juveniles. Aquaculture Nutrition, 3(1), 49-53.

Church, D.C and W.G. Pound., 1982. Basic Animal Nutrition and Feeding. $2^{\text {nd }}$ Ed. John Wiley \& Sons, New York 10016, USA.

Cornelius, C. and J.J. Kaneko, 1963. Clinical biochemistry of Domestic Animals. Pp. 162. Academic Press.

Daghash., M.W.H., 2015. The impact of using mannan oligosaccharides as growth promoter on the productive performance of male sheep in Upper Egypt. Ph.D. Thesis, Faculty of Agriculture, Assiut University, Egypt.

Davis, M.E., C.V. Maxwell, D.C. Brown, B.Z. deRodas, Z.B. Johnson, E.B. Kegley, D.H. Hellwig and R.A. Dvorak, 2002. Effect of dietary mannan oligosaccharide and (or) pharmacological additions of supplemental copper on growth performance and immune-competence of weanling and growing/finishing pigs. Journal of Animal Science, 80: 2887-2894.

Delzenne N.M and N. Kok., 1998. Effect of no digestible fermentable carbohydrates on hepatic fatty acid metabolism. Biochemical Society Transactions, 26: 228-30.
Demirel, G., N. Turan, A. Tanor, N. Kocabagli, M. Alp, M. Hasoksuz, and H. Yilmaz, 2007. Effects of dietary mannan oligosaccharide on performance, some blood parameters, IgG levels and antibody response of lambs to parenterally administered E. coli O157:H7. Archives of animal nutrition, 61(2):126-134.

Diaz, T.G., A.F. Branco., F.A. Jacovaci., C.C. Jobim., J.L.P. Daniel., A.V.I. Bueno and M.G. Ribeiro, 2018. Use of live yeast and mannanoligosaccharides in grain-based diets for cattle: Ruminal parameters, nutrient digestibility, and inflammatory response. PloS one, 13(11).

Djouzi, Z. and C. Andlueux, 1997. Compared effects of three oligosaccharides on metabolism of intestinal microflora in rats inoculated with a human faecal flora. British Journal of Nutrition, 78(2), 313-324.

Duan X. D., D.W. Chen., P. Zheng., G. Tian., J.P. Wang., X.B. Mao., J. Hu., J. He., B. Li., Z.Q. Huang, 2016. Effects of dietary mannan oligosaccharide supplementation on performance and immune response of sows and their offspring. Animal Feed Science and Technology, 218:1725.

Fath Allah, M., 2006. The effect of genotype and growth promoter on some performance traits of fattening lambs. Ph.D. Thesis, Faculty of Veterinary Medicine, Alexandria University.

Franklin, S.T., M.C. Newman, K. E. Newman and K.I. Meek, 2005. Immune parameters of dry cows fed mannan oligosaccharides and subsequent transfer of immunity to calves. Journal of dairy science, 88(2): 766-775.

Ghosh, S. and R.K. Mehla, 2012. Influence of dietary supplementation of prebiotics (mannan oligosaccharide) on the performance of crossbred calves. Tropical animal health and production, 44(3), 617-622.

Gibson, G. R. and M. B. Roberfroid, 1995. Dietary modulation of the human colonic microbiota: introducing the concept of prebiotics The Journal of nutrition, 125(6), 1401-1412.

Grand, E., F. Respondek, C. Martineau, J. Detilleux, and G. Bertrand., 2013. Effects of short-chain fructooligosaccharides on growth performance of preruminant veal calves. Journal of dairy science, 96(2), 1094-1101.

Hadley, M.E., 1984. Pancreatic hormones and metabolic regulation, thyroid hormones and hormones of males' reproductive physiology. Prentice-Hall, Inc., Englewood Cliffs, New Jersy, 235-263.

Hassan, I., A.G. Abdallh, and S. Abo-El-Wafa., 1996. Utilization of decorticated local cottonseed meal in broiler diets. Egyptian Poultry Science Journal (Egypt), 31-49.

Heinrichs, A. J., B. S. Heinrichs, and C. M. Jones., 2013. Fecal and saliva IgA secretion when feeding a concentrated mannan oligosaccharide to neonatal dairy calves. The Professional Animal Scientist, 29(5), 457-462. 
Iji, P.A., A.A. Saki and D.R. Tivey, 2001. Intestinal structure and function of broiler chickens on diets supplemented with a mannan oligosaccharide. Journal of the Science of Food and Agriculture, 81(12), 1186-1192.

Jayabal, T., Ra. Murallidharan, P. Tensingh Gnanaraj, and M. Murugan, 2008. Growth performance of stall-fed goats under probiotic supplementation. Tamilnadu J. Veterinary \& Animal Science, 4 (5): 179-184.

Jin L., Dong G.Z., Lei C.L., Zhou J., and S. Zhang. 2014. Effects of dietary supplementation of glutamine and mannan oligosaccharides on plasma endotoxin and acute phase protein concentrations and nutrient digestibility in finishing steers.Journal of Applied Animal Research, 42(2), 160-165.

Kanakupt, K., B.M. Vester Boler, B.R. Dunsford and G.C. Fahey, 2011. Effects of short-chain fructooligosaccharides and galactooligosaccharides, individually and in combination, on nutrient digestibility, fecal fermentative metabolite concentrations, and large bowel microbial ecology of healthy adults cats. Journal of Animal Sciences, 89(5):1376-1384.

Kaneko, J.J., 1998. Thyroid function. In: Clinical Biochemistry of Domestic Animals, pp.630-649. $\left(4^{\text {th }}\right.$ Ed.) Academic Pres. A division Harcourt brace, company, Sandiago, New York, Boston, Sydney, Tokyo and Toronto. .

Liang, J., Melican, D., Cafro, L., Palace, G., Fisette, L., Armstrong, R. and M.L. Patchen, 1998. Enhanced clearance of a multiple antibiotic resistant Staphylococcus aureus in rats treated with PGG-glucan is associated with increased leukocyte counts and increased neutrophil oxidative burst activity. International journal of immunopharmacology, 20(11): 595-614.

Linneen S.K., Mourer G.L., Sparks J.D., Jennings J.S., Goad C.L and D.L. Lalman., 2014. Effects of mannan oligosaccharide on beef-cow performance and passive immunity transfer to calves.The Professional Animal Scientist, 30(3):311-317.

Liu, P.; X.S. Piao, S.W. Kim, L. Wang, Y.B. Shen, H.S. Lee and S.Y. Li., 2008. Effects of chitooligosaccharide supplementation on the growth performance, nutrient digestibility, intestinal morphology, and fecal shedding of Escherichia coli and Lactobacillus in weaning pigs. Journal of Animal Sciences, 86(10): 2609-2618.

Lowry, V.K., Farnell, M.B., Ferro, P.J., Swaggerty, C.L., Bahl, A. and M.H. Kogut., 2005. Purified glucan as an abiotic feed additive upregulates the innate immune response in immature chickens against Salmonella entericserovarEnteritidis. Int. J. Food Microbiology, 98:309-318.

Macfarlane, G.T. and Cummings, J.H., 1991. The colonic flora, fermentation and large bowel digestive function. In The Large Intestine: Physiology, Pathophysiology and Disease, pp.
51-92 [S. F. Phillips, J. H.Pemberton and R. G. Shorter, editors]. New York: Raven Press.

Maha M. Hady, R.A. EL-Banna, H.M. Teleb, and R.A. Shimaa. 2012. Impact of Manna Oligosaccharide (Bio-Mos ${ }^{\circledR}$ ) and Esterified Glucomannan $\quad\left(\right.$ MTB-100 $\left.{ }^{\circledR}\right)$ Dietary Supplementation on Performance and Health Status of Barki Lambs Under Egyptian Conditions. International Journal of Chemical Engineering and Applications, 3(4):264.

Mandour, M.A., S.A. Al-Shami' T. A. Foudaand G. F. Al-Tabari., 2010. Effects of yeast as direct-fed microbes on rumen microbial ecology and productive performance of Saudi Arabia sheep during fattening.www.kfu.edu.sa

More, T., Rai, A.K. and Manohar, S.,1980. Note on the effect of thermal exposure on body fluid composition of different breeds and breed crosses of sheep. Indian Journal of Animal Sciences, 50(2), 207-209.

Morrison, S.J., Dawson, S., and Carson, A.F., 2010. The effects of mannan oligosaccharide and Streptococcus faecium addition to milk replacer on calf health and performance. Livestock Science, 131(2-3), 292-296

Parshad, O. and A.Singh., 1979. Effect of altered thyroid status on PBI, blood glucose, plasma cholesterol, liver glycogen and oxygen consumption by liver of gonads of poultry. Indian Journal of Animal Sciences (India), 49: 446-450.

Poeikhampha, T. and C. Bunchasak., 2011. Comparative Effects of Sodium Gluconate, Mannan oligosaccharide and Potassium Diformate on Growth Performances and Small Intestinal Morphologyof Nursery Pigs. Asian-Australasian Journal of Animal Sciences, 24(6): 844-850.

Ranjhan, S. K., 1980. Animal nutrition and feeding practice in India. Vikas Publishing House, New Delhi, $350 \mathrm{p}$.

Roberfroid M., 2002. Functional food concept and its application to prebiotics. Digestive and Liver Disease. ; 34: 105-10.

SAS Institute Inc., 2004. SAS procedures Guide for personal Computers, Statistical Analysis System Institute, Inc., Cary. N.C.

Smith, E. L., R. L. Hill, I. R. Lehman, R. J. Lefkowitz, P. H. Handler and A. White. 1983. The thyroid. In: Principles of Biochemistry: Mammalian Biochemistry (7 ${ }^{\text {th }}$ Ed.). PP 416440.mCgRAW Hill Book Co., New York.

Steel, R.G.D. and J.H. Torrie., 1980. Principles and procedures of Statistical: A Biometrical Approach (2 ${ }^{\text {nd }}$ Ed.). MacGraw-Hill Book Co., New York.

Van Dokkum W, Wezendonk B, Srikumar T.S and E.G. van den Heuvel., 1999. Effect of nondigestible oligosaccharides on large bowel functions, blood lipid concentrations and glucose absorption in young healthy male subjects. European Journal of Clinical Nutrition, 53(1): 17. 
Weiss, W.P., 1999. Energy prediction equations for ruminant feeds. Proc. Corn. Nut. Conf. Feed Manuf., 61, 76-185.

White, L.A., Newman, M.C.; Cromwell, G.L. and M.D Lindemann., 2002. Brewers dried yeast as a source of mannan oligosaccharides for weanling pigs. Journal of Animal Science, 80(10):26192628.

Yasar, S. and J.M. Forbes, 1999. Performance and gastrointestinal response of broiler chicken fed on cereal gain-based foods soaked in water. British poultry science,40(1): 65-76.
Zhao, P. Y., J. H. Jung, and I. H. Kim., 2012. Effect of mannan oligosaccharides and fructan on growth performance, nutrient digestibility, blood profile, and diarrhea score in weanling pigs. Journal of Animal Science, 90:833-9.

Zheng C., F. Li, Z. Hao and T. Liu., 2018. Effects of adding mannan oligosaccharides on digestibility and metabolism of nutrients, ruminal fermentation parameters, immunity, and antioxidant capacity of sheep. Journal of Animal Science, 96 (1): 284-292.

\section{تأثثير التظذية بأنواع مختلفة من الأوليجوسكريدات على أداء النمو والهضم وبعض مقاييس الدم لذكور الجاموس}

محترم عبدالله محمد ابر اهيم'، إكر امي حامد صادق حسن' ، محمد وائل حسن دغث '

ا ـقسم الانتاج الحيواني، كلية الزراعة جامعة الأزهـر فرع أسيوط، ب ـ قسم الانتاج الحيواني، كلية الزراعة، جامعة أسيوط

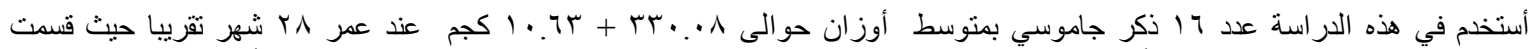

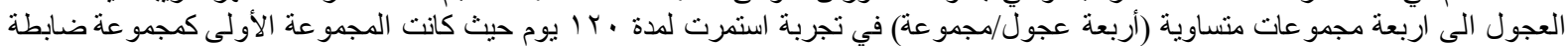

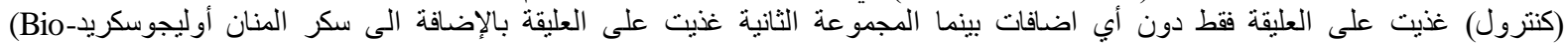

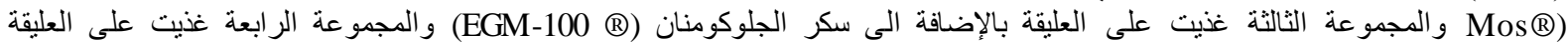

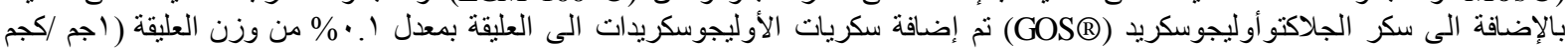

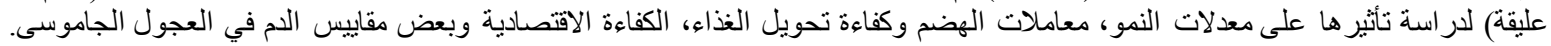

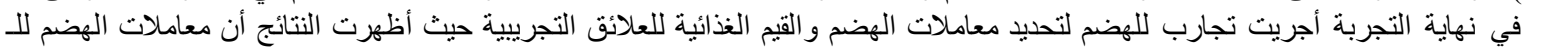

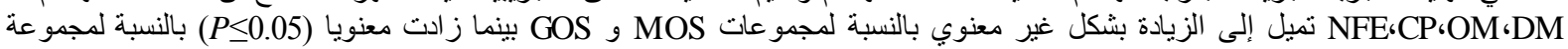

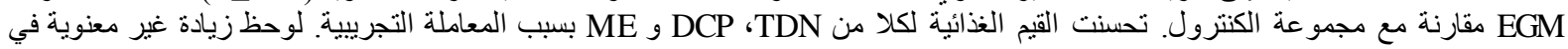

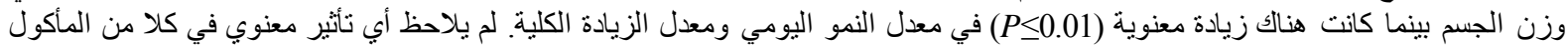

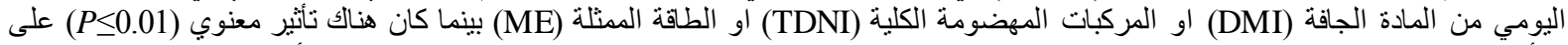

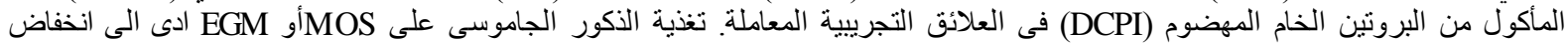

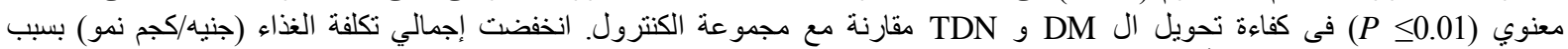

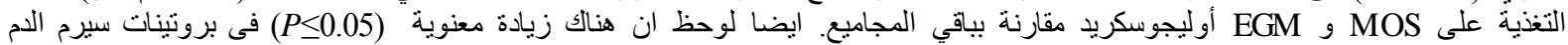

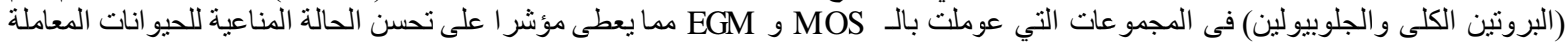

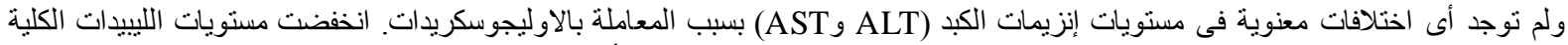

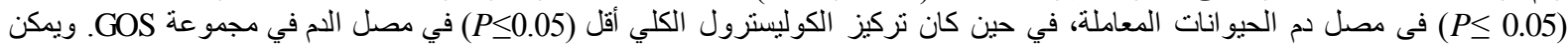

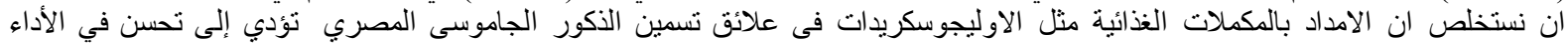

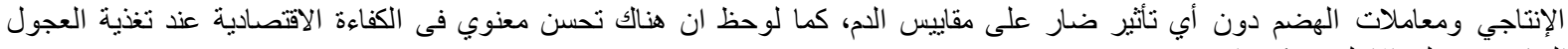

